\title{
ANTIBIOTIC THERAPY OF CHRONIC POST-TRAUMATIC OSTEOMYELITIS
}

\author{
G. Hierholzer, ${ }^{*}$ Duisburg, Germany, J. Rehn, $†$ Bochum, Germany, \\ H. Knothe, Frankfurt, Germany, and J. Masterson,§ Dublin, Eire
}

Many therapeutic approaches to the management of chronic post-traumatic osteomyelitis have been proposed and studied (Neuber 1896, Blanke 1952, Bischofberger 1953, Kosinzew 1954, Ruhl 1954, Nikitin 1955, Endler 1957, Lerch 1957, Bikfalvi and Ecke 1960, Thörmer 1960, Wynn 1960, Axhausen 1961, Compere 1962, Färber 1962, Murray 1962, Willenegger 1963, Dahmen 1965). The condition, because of its potentially crippling local and systemic sequelae, is one which demands thorough and energetic treatment, and the changing microbiological patterns of the illness make it imperative to keep the methods of treatment under constant review. Furthermore, the frequency of relapse in this chronic bone disease necessitates observation for several years in the course of a single illness before any claim for clinical cure can be made (Blanke 1952, Dahmen 1965).

The basic principles of therapy in chronic post-traumatic osteomyelitis are surgical removal of foci of chronic bone sepsis, and support of the defence mechanisms of the body against the causative organism. The present paper will deal mainly with the latter aspect of treatment.

It is essential to emphasise that in the management of chronic post-traumatic osteomyelitis antibiotics can usefully supplement the body's defence mechanisms but must never be regarded as a substitute for surgery. Appropriate antibiotic therapy can play a valuable role by preventing local and general spread of infection, especially during operative procedures, and by controlling the infection itself.

TABLE I

Modes of Action and Therapeutic Applications of Different Antibiotics

\begin{tabular}{|llll|}
\hline \multicolumn{1}{|c|}{ Mechanism of action } & & Examples & Type of inflammation \\
\hline $\begin{array}{l}\text { Affecting synthesis of cell } \\
\text { wall substances }\end{array}$ & & $\begin{array}{l}\text { Penicillins } \\
\text { Cephalosporins }\end{array}$ & Acute \\
\cline { 1 - 2 } $\begin{array}{l}\text { Inhibiting general protein } \\
\text { synthesis or intermediate } \\
\text { metabolic products } \cdot\end{array}$ & $\begin{array}{l}\text { Fusidic acid } \\
\text { Lincomycin } \\
\text { Kanamycin } \\
\text { Tetracyclines } \\
\text { Chloramphenicol }\end{array}$ & Acute and chronic \\
\hline $\begin{array}{l}\text { Altering the permeability of } \\
\text { the cytoplasmic membrane }\end{array}$ & $\begin{array}{l}\text { Gramicidin } \\
\text { Polymyxins }\end{array}$ & Acute and chronic \\
\hline
\end{tabular}

The clinical and morphological differences between the acute and chronic forms of osteomyelitis have important implications for antibiotic therapy of these conditions. Because it is hyperaemic and rich in cells, acutely inflamed tissue provides a good medium for the growth of pathogenic organisms. Under such conditions of rapid bacterial proliferation the classical mechanism of action of bactericidal antibiotics-that is, an effect on cell wall synthesis-can be used to good effect (Table I). In chronic post-traumatic osteomyelitis, on the other hand, the characteristic morphological features are dense sclerosis and impairment of circulation. Such lesions provide a less favourable milieu for bacterial proliferation and are best treated by antibiotics with an inhibitory effect on bacterial protein synthesis or a damaging effect on existing bacterial cell wall structure (Table I).

\footnotetext{
* Director, Employers' Liability Insurance Accident Clinic, Duisburg-Buchholz.

+ Chief of Service, Surgical Clinic and Policlinic of the Bergmannsheil Employers' Liability Insurance Hospital, Bochem.

¥ Director, Institute for Medical Microbiology, University of Frankfurt.

Department of Pathology, University College, Dublin.
}

VOL. 56 B, NO. 4, NOVEMBER 1974 
The most fundamental questions to be asked concerning the choice of an antibiotic for supportive systemic therapy of chronic post-traumatic osteomyelitis are: 1) is this antibiotic effective against the causative organism? 2) Is it likely to be effective under the bacterial metabolic conditions peculiar to chronic osteomyelitis? 3) Can the antibiotic penetrate the dense sclerotic lesions of chronic osteomyelitis in therapeutically useful concentrations? 4) Is the treatment safe?

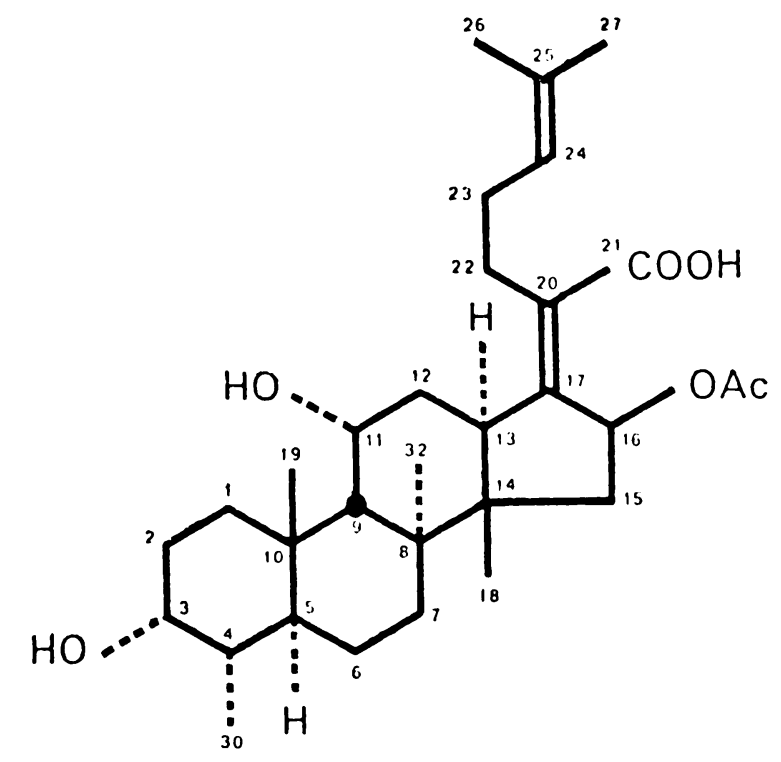

FIG. 1

Fusidic acid.

Although infections caused by gram negative bacilli and mixed infections are now more commonly seen in chronic osteomyelitis (Clawson and Dunn 1967; Agranat 1969), most cases are still caused by staphylococci (Garrod and O'Grady 1971). We have therefore considered the above desiderata in relation to the potent anti-staphylococcal antibiotic, fusidic acid.

Fusidic acid belongs to the group of steroid antibiotics and has proved to be a substance of real therapeutic significance. Its chemical structure, which was elucidated by Godtfredsen and Vangedal (1962), is shown in Figure 1. Although it is also active against corynebacteria, clostridia, neisseria and Mycobacterium tuberculosis, its main activity is against coagulasepositive Staphylococcus aureus, including penicillinase-producing strains and strains with multiple antibiotic resistance. The investigations of Newman, Bhat, Hackney, Robinson and Stewart (1962) and of Barber and Waterworth (1962) indicate that fusidic acid has mainly a bactericidal action. The mode of action of fusidic acid has been elucidated independently by Harvey, Knight and Sih (1966), by Yamaki (1965) by Tanaka, Yamaki, Lin and Umezawa (1967) and by Tanaka, Kinoshita and Masukawa (1968), and their findings indicate that it appears to act by inhibition of bacterial protein synthesis. After many years of clinical use in patients of all ages, in high dosage and for periods of several months, no established pattern of toxicity to this antibiotic has emerged.

It can be seen that clinical experience and theoretical considerations have yielded positive answers to some of the above questions with respect to fusidic acid. In particular, however, the answer to the question of penetration of the antibiotic into chronic inflammatory bone lesions could only be provided by combined surgical and microbiological experimental procedures. Most of the investigations that we reviewed (Hierholzer, Knothe, Rehn and Koch 
1966; Hierholzer and Rehn 1966; Hierholzer and Rehn 1967; Hierholzer, Rehn, Koch and Gatos 1967; Hierholzer, Linzenmeier and Knothe 1969; Hierholzer 1970; Hierholzer, Knothe and Rehn 1970) were designed to elucidate this problem.

\section{THE INVESTIGATIONS}

The following studies were undertaken. 1) Swabs were taken from a large series of patients in our unit for infected cases to determine the prevalence of pathogenic staphylococci in the lesions of such patients. 2) The sensitivity of staphylococci from 150 such swabs to fifteen different antibiotics was determined. 3) The bacteriological results following oral fusidic acid therapy in 100 patients with confirmed staphylococcal infection were assessed. No other antibiotics were administered during the treatment. 4) Bone samples were taken at operation after treatment for not less than five days with fusidic acid in a series of patients with chronic osteomyelitis. In most cases the osteomyeiitis was of the post-traumatic variety and most bone samples were taken from the upper or lower leg. The fusidic acid (as sodium fusidate) dosage regime in fifteen patients was 0.5 gram three times daily orally and a further fourteen patients received 1 gram three times daily also by mouth. The last dose was given two to five hours before operation. Rectangular bone samples taken at operation measured approximately $2 \times 0.5 \times 0.5$ centimetres and weighed between 2 and 5 grams. Most samples were taken from areas which on macroscopic examination appeared relatively avascular. With the exception of actual sequestra, however, some small blood vessels could be seen microscopically. Care was taken to avoid, as far as possible, contamination of the bone samples by blood or serum, and immediately after removal each specimen was gently rolled in cotton wool dampened with physiological saline to further ensure removal of any extraneous contamination. The samples were then wrapped in sterile gauze and stored in a sterile vessel; they were later weighed, ground in a mortar and eluted with a measured volume of phosphate buffer (pH 6.8) before assay of antibiotic content by the agar plate diffusion method. 5) Serum and bone samples were taken at operation from a total of thirty-one patients with aseptic, non-inflammatory bone conditions. In most instances the relevant surgical procedures were corrective osteotomy and osteosynthesis. Fusidic acid was given in the form of its sodium salt at an oral dosage of 0.5 gram three times daily. The treatment periods before operation were five days (nine patients), six to ten days (fifteen patients) and more than ten days (seven patients). Serum samples were taken before anaesthesia and bone samples were taken at operation and processed as described above. In twelve cases the amount of bone obtained was sufficient to permit separate assays of antibiotic levels in compact and cancellous bone.

RESULTS

1) Swabs taken from a large variety of lesions in the hospital infective unit showed the presence of pathogenic staphylococci in 89.9 per cent of cases (Table II).

TABLE II

Demonstration of Staphylococcus Aureus in Swabs from the Unit FOR INFECTIVE CASES

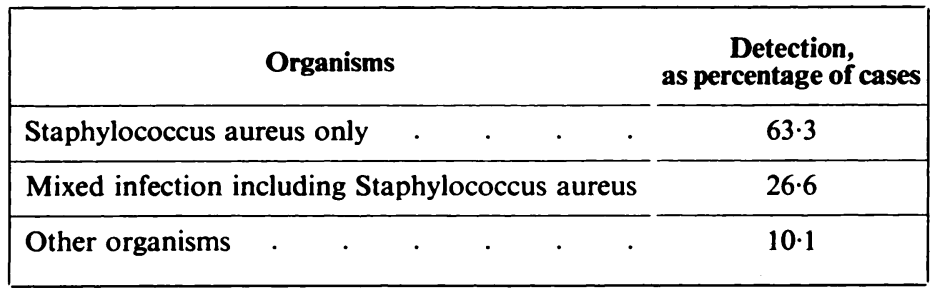

2) The results of multiple antibiotic sensitivity testing on 150 staphylococci isolated from such swabs are shown in Table III. It will be noted that of the 150, 147 were sensitive to fusidic acid, two were slightly sensitive and only one was resistant. 
3) The in vitro efficacy of fusidic acid was confirmed by the achievement of a sterile swab in a high percentage of staphylococcal infections after systemic treatment. Thus, in 77 per cent of cases no growth was obtained after treatment and in the remaining 23 per cent a change of flora was detected (Table IV). Evidence of recurrent staphylococcal infection was noted

TABLE III

Results of Multiple Antibiotic Sensitivity Tests on 150 Isolated Strains of Staphylococci

\begin{tabular}{|c|c|c|c|c|c|c|c|c|}
\hline & & Sensitive & $\begin{array}{l}\text { Slightly } \\
\text { sensitive }\end{array}$ & Insensitive & & Sensitive & $\begin{array}{l}\text { Slightly } \\
\text { sensitive }\end{array}$ & Insensitive \\
\hline Penicillin . & . & 32 & 4 & 114 & Streptomycin & 87 & 4 & 59 \\
\hline Propicillin. & . & 34 & 7 & 109 & Kanamycin. & 136 & 3 & 11 \\
\hline Methicillin & . & 141 & 3 & 6 & Neomycin . & 135 & 7 & 8 \\
\hline Oxacillin & . & 140 & 2 & 8 & Tetracycline group & 95 & 21 & 34 \\
\hline Ampicillin & . & 41 & 26 & 83 & Chloramphenicol. & 126 & 17 & 7 \\
\hline Erythromycin & . & 141 & 3 & 6 & Furacin & 119 & 25 & 6 \\
\hline Oleandomycin & . & 142 & 4 & 4 & Fucidin & 147 & 2 & 1 \\
\hline Novobiocin & . & 139 & 4 & 7 & & & & \\
\hline
\end{tabular}

TABLE IV

Bacteriological Results from Swabs from 100 Patients with Staphylococcal Infections AFTER THERAPY WITH FUSIDIC ACID

\begin{tabular}{|c|c|c|c|c|}
\hline Diagnosis & & $\begin{array}{c}\text { Number of } \\
\text { patients }\end{array}$ & Sterile & $\begin{array}{l}\text { Transition } \\
\text { to other } \\
\text { organisms }\end{array}$ \\
\hline Chronic post-traumatic osteomyelitis & . & 72 & 54 & 18 \\
\hline Staphylococcal infection following burnir & ng & 2 & 2 & - \\
\hline Chronic purulent inflammation of bursal & mucosa & 1 & 1 & - \\
\hline Secondary wound infection & . & 16 & 12 & 4 \\
\hline Chronic ulcer with deficient blood flow & . & 6 & 6 & - \\
\hline Carbuncle . & . & 3 & 2 & 1 \\
\hline
\end{tabular}

TABLE $V$

Bacteriologically Active Concentrations of Fusidic Acid in Chronically Inflamed Bony Tissue

\begin{tabular}{|c|c|c|c|c|}
\hline \multirow{2}{*}{ Group } & \multirow{2}{*}{$\begin{array}{l}\text { Number of } \\
\text { patients }\end{array}$} & \multirow{2}{*}{$\begin{array}{c}\text { Grams fusidic acid } \\
\text { per day } \\
\text { (for at least } \\
5 \text { days) }\end{array}$} & \multicolumn{2}{|c|}{$\begin{array}{c}\text { Fusidic acid concentration } \\
(\mu \mathrm{gram} / \mathrm{gram} \text { tissue })\end{array}$} \\
\hline & & & Range & Mean \\
\hline I & 15 & 1.5 & $1 \cdot 7-14 \cdot 9$ & $7 \cdot 3$ \\
\hline II & 14 & $3 \cdot 0$ & $3 \cdot 4-14 \cdot 8$ & $9 \cdot 8$ \\
\hline
\end{tabular}

in six patients after withdrawal of antibiotic therapy. It was not possible to determine whether these were reinfections with the original staphylococcus or superinfections with some other strain. Sterile swabs were once more obtained from these, however, when antibiotic treatment was reinstituted. 
4) Table V shows the bacteriologically active concentrations of fusidic acid detected in the chronically inflamed bone removed at operation. Comparison of the levels achieved in the two treatment groups shows that there does not appear to be any great advantage in using a dosage of more than 2 grams a day administered orally.

5) The bacteriologically effective levels of serum and bone fusidic acid in the three groups of patients operated on for aseptic, non-inflammatory bone conditions are summarised in Table VI. Cumulative average bone concentrations are noted with increasing duration of treatment and the levels are, as might be expected, higher than those observed in the samples removed from chronic inflammatory lesions. The higher average serum level in group II is noteworthy but difficult to explain. It may reflect the fact that it represents the average of a much larger group of patients than the other two, and it may also have been influenced by varying degrees of protein binding of the antibiotic. It is not surprising that in those cases in which separation was possible, higher fusidic acid levels were detected in the more vascular cancellous bone than in the compact bone (Table VII).

Side-effects-In some patients gastro-intestinal side-effects occurred, which, however, always disappeared with the use of a spasmolytic agent.

TABLE VI

Bacteriologically Effective Fusidic Acid Levels in Serum and Non-inflammatory Bone Tissue (Dosage $3 \times 500$ milligrams per day)

\begin{tabular}{|c|c|c|c|c|c|c|}
\hline \multirow{2}{*}{ Group } & \multirow{2}{*}{$\begin{array}{c}\text { Number of } \\
\text { patients }\end{array}$} & \multirow{2}{*}{$\begin{array}{c}\text { Number of } \\
\text { treatment } \\
\text { days }\end{array}$} & \multicolumn{2}{|c|}{$\underset{(\mu \mathrm{gram} / \text { millilitre })}{\text { Serum }}$} & \multicolumn{2}{|c|}{ 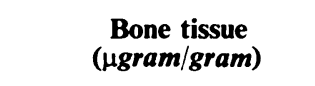 } \\
\hline & & & $\begin{array}{c}\text { Range of } \\
\text { measurement }\end{array}$ & Average & $\begin{array}{c}\text { Range of } \\
\text { measurement }\end{array}$ & Average \\
\hline I & 9 & 5 & $1 \cdot 6-108 \cdot 8$ & $26 \cdot 7$ & $1 \cdot 2-40 \cdot 21$ & $12 \cdot 3$ \\
\hline II & 15 & 7 & $5 \cdot 1-166 \cdot 4$ & $44 \cdot 7$ & $2 \cdot 3-75 \cdot 1$ & $21 \cdot 3$ \\
\hline III & 7 & 13 & $2 \cdot 7-58 \cdot 8$ & $27 \cdot 1$ & $2 \cdot 8-79 \cdot 1$ & $25 \cdot 4$ \\
\hline
\end{tabular}

TABLE VII

Average Bacteriologically Effective Fusidic Acid Levels in SERUM AND Bone TISSUE

(Dosage $3 \times 500$ milligrams/day)

\begin{tabular}{|c|c|c|c|c|}
\hline \multirow{2}{*}{$\begin{array}{l}\text { Number of } \\
\text { patients }\end{array}$} & \multirow{2}{*}{$\begin{array}{c}\text { Number of } \\
\text { treatment } \\
\text { days }\end{array}$} & \multirow{2}{*}{$\underset{(\mu \text { gram/millilitre })}{\text { Serum }}$} & \multicolumn{2}{|c|}{ 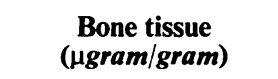 } \\
\hline & & & Corticalis & Spongiosa \\
\hline 12 & $7 \cdot 7$ & 39.9 & $17 \cdot 9$ & 31.9 \\
\hline
\end{tabular}

\section{DISCUSSION}

The earliest part of the present series of investigations was that dealing with the prevalence of staphylococci in the various lesions encountered in our unit for infective cases. These studies were initiated several years ago and, while the prevalence is unlikely to be as high as 89.9 per cent at the present time, the role of staphylococci in the aetiology of serious infective lesions requiring operation remains dominant. Our choice of fusidic acid as a therapeutic agent in chronic post-traumatic osteomyelitis was dictated by early encouraging clinical reports (Taylor and Bloor 1962, Chater 1963, Arens and Thiele 1966) and by the in vitro efficacy of this antibiotic against a large number of staphylococcal isolates (Table III). Further clinical experience (Table IV) confirmed the therapeutic excellence of fusidic acid in a variety of staphylococcal infective lesions, including many cases of chronic post-traumatic osteomyelitis. 
When prescribing antibiotic treatment for chronic bone infections it is imperative to know something about the ability of these substances to penetrate the lesions, and this can be determined only by assaying the bacteriologically active form of the drug in chronic inflammatory bone. In 1953 Juch found low tissue concentrations in normal cancellous bone after administration of penicillin. In retrospect these results could possibly be explained by the low penicillin doses which were still in use at that time. Qualitative demonstrations and

TABLE VIII

Bacteriologically EFFective CONCENTRATIONS OF LiNCOMYCIN IN Chronically Inflamed Bone Tissue

\begin{tabular}{|c|c|c|c|c|}
\hline $\begin{array}{c}\text { Case } \\
\text { number }\end{array}$ & $\begin{array}{c}\text { Chronic } \\
\text { osteomyelitis }\end{array}$ & $\begin{array}{c}\text { Days of } \\
\text { treatment }\end{array}$ & $\underset{(\mu \text { gram } / \text { millilitre })}{\text { Serum }}$ & $\begin{array}{c}\text { Bone } \\
(\mu \text { gram } / \text { gram })\end{array}$ \\
\hline 1 & Femur & 3 & $4 \cdot 80$ & - \\
\hline 2 & Tibia & 5 & $7 \cdot 50$ & 3.00 \\
\hline$\frac{\pi}{5} 3$ & Tibia & 6 & 4.90 & 2.00 \\
\hline 吝 4 & Femur & 7 & $2 \cdot 03$ & - \\
\hline$\frac{5}{5} 5$ & Hallux & 8 & 1.90 & $1 \cdot 32$ \\
\hline 6 & Tibia & 10 & $7 \cdot 74$ & - \\
\hline $\begin{array}{ll}\overline{\bar{E}} & 7 \\
0 & \end{array}$ & Tibia & 11 & 6.48 & 1.94 \\
\hline$\frac{8}{x} 8$ & Femur & 13 & $5 \cdot 71$ & $2 \cdot 61$ \\
\hline${ }^{m} 9$ & Tibia & 14 & $2 \cdot 73$ & - \\
\hline 10 & Tibia & 20 & $4 \cdot 14$ & $1 \cdot 70$ \\
\hline \multirow{10}{*}{ 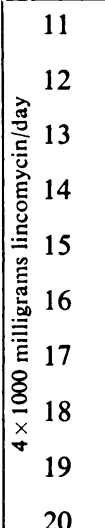 } & Hip joint & 2 & $7 \cdot 74$ & $2 \cdot 40$ \\
\hline & Femur & 3 & $11 \cdot 16$ & $2 \cdot 73$ \\
\hline & Tibia & 3 & $2 \cdot 22$ & $2 \cdot 27$ \\
\hline & Tibia & 3 & $12 \cdot 63$ & $2 \cdot 50$ \\
\hline & Tibia & 4 & $2 \cdot 40$ & 1.43 \\
\hline & Tibia & 4 & $8 \cdot 88$ & - \\
\hline & Hallux & 6 & $3 \cdot 81$ & $3 \cdot 53$ \\
\hline & Femur & 6 & $10 \cdot 44$ & $2 \cdot 93$ \\
\hline & Femur & 10 & $5 \cdot 22$ & 2.93 \\
\hline & Tibia & 11 & $3 \cdot 16$ & $4 \cdot 61$ \\
\hline
\end{tabular}

chemical determinations of various antibiotics have also been carried out (Buyske, Eisner and Kelly 1960; Holloway, Kahlbaugh and Scott 1964), but these methods are just as unreliable as blood levels for quantitative assessment of antibacterial activity in the bony lesion itself. It was therefore of the utmost theoretical and practical interest to demonstrate the ability of fusidic acid, orally administered, to penetrate both normal and chronically inflamed bone in therapeutically significant concentrations. The levels detected in samples taken from aseptic, non-inflammatory bone lesions were higher than those observed in chronic inflammatory lesions and probably reflect the presence of a better blood supply in the former. The cumulative average bone concentrations found with increasing duration of treatment were also noteworthy. A study of serum and bone levels of lincomycin following administration of this antibiotic to 
twenty patients with chronic inflammatory bone disease failed to demonstrate such cumulation with increasing duration of dosage (Table VIII). Similar negative findings have been recorded with respect to dicloxacillin.

The bacteriologically active concentrations of fusidic acid found in samples of chronically inflamed bone must be evaluated in relation to the known antistaphylococcal activity of this antibiotic. Reports in the literature (Barber and Waterworth 1962; Godtfredsen, Jahnsen, Lorck, Roholt and Tybring 1962; Crosbie 1963; Stewart 1964) indicate that a 50 per cent growth inhibition is achieved in vitro with an inoculum of $10^{4}-10^{5}$ organisms at concentrations of 0.03-0.05 microgram per millilitre. A twofold to fourfold increase of concentration could achieve a minimum bactericidal level (Hilson 1962, Kimmig and Meyer-Rohn 1962, Ritzerfeld 1964, Stewart 1964). There are no reports available of bacterial counts in chronically inflamed bone but it can be pointed out that even in pyaemia there are only likely to be about $10^{6}$ organisms per millilitre of blood. It is therefore reasonable to conclude that the local concentrations of fusidic acid found after oral treatment are sufficient to inhibit the growth of staphylococci in chronically inflamed bone.

In vitro studies have shown that resistance can be induced relatively easily by passage of a sensitive strain of staphylococci through successive sub-inhibitory concentrations of Fucidin. The ease with which tolerance to Fucidin develops in vitro has not, however, been reflected in general clinical experience of the antibiotic (Taylor and Bloor 1962, Crosbie 1963). Combinations of Fucidin and another antibiotic have been used both to achieve an enhanced effect and to prevent the development of resistant strains. Jensen and Kiaer (1964) found that Fucidin acts synergistically with methicillin, novobiocin, tetracycline and erythromycin under certain circumstances. They further observed that combinations of Fucidin with penicillin, methicillin, novobiocin or tetracycline, which alone caused no appreciable inhibition of the staphylococci, killed any Fucidin-resistant mutants. Although Fucidin alone was used in the present study, it would seem logical on this basis to consider the use of combination therapy, especially if there is a risk of the emergence of resistant strains during long-term treatment.

The antibacterial spectrum of Fucidin includes Mycobacterium tuberculosis, although it is only a very weak inhibitor of this organism. It could therefore be postulated that co-existent tuberculosis might be masked but inadequately treated during Fucidin therapy of a chronic staphylococcal infection. The lack of effect of Fucidin against tuberculosis in animal experiments and clinical trials, however, indicates that this is a theoretical rather than a practical objection.

It is not suggested on the basis of the present study that general antibiotic prophylaxis is indicated for all bone operations. In our opinion it is principally indicated before and after operation for saucerisation of chronically inflamed bone foci, and also in secondary infection after osteosynthesis. In the latter instance, effective antibiotic therapy can maintain control of the infection until bone growth allows surgical removal of the metal. In this way the osteosynthetic material can be left in position until it is no longer required to ensure the stability of the fractured area. Its eventual removal will make an important contribution to the elimination of any existing infection. Meanwhile the choice of supportive antibiotic therapy should at all times be monitored by bacterial culture and sensitivity determinations.

Reference must be made to the ancillary effect of through drainage in chronic posttraumatic osteomyelitis. In the presence of bony cavities with accumulations of pus and necrotic debris the mechanical rinsing effect of such drainage can provide a valuable supplement to surgical procedures and systemic antibiotic therapy. It is unrealistic to expect that the addition of antibiotics to the rinsing fluid can provide an adequate substitute for systemic therapy, but this expedient may be intermittently employed with a view to preventing superinfection.

Finally, in view of the results discussed above it no longer seems reasonable to take a 
pessimistic view of the ability of antibiotics to penetrate into chronically inflamed tissue, and we are justified therefore in administering suitable antibiotics not only to protect the patient from infection but also to influence the course of inflammation in chronic osteomyelitis. In this way the essential surgical procedures in chronic post-traumatic osteomyelitis can be rendered safer and more efficacious.

\section{SUMMARY}

1. The dominant role of pathogenic staphylococci in surgical infections has been confirmed by positive isolations in 89.9 per cent of a wide variety of lesions in a hospital infective unit. Of 150 staphylococci isolated, 147 were sensitive to fusidic acid, two were slightly sensitive and only one was resistant.

2. Fusidic acid was administered as sodium fusidate to 100 patients with staphylococcal infections (including seventy-two with chronic post-traumatic osteomyelitis). Sterile swabs were achieved in seventy-seven of these patients and in the remaining twenty-three a change of flora was detected.

3. Bone samples were taken at operation from twenty-nine patients with chronic osteomyelitis who had been treated for at least five days with fusidic acid. Depending on dosage, the mean fusidic acid concentrations were 7.3 and 9.8 micrograms per gram. Corresponding levels in non-inflammatory bone samples from thirty-one patients were, depending on the duration of treatment, 12.3, 21.3 and 25.4 micrograms per gram. The fusidic acid levels in cancellous bone were almost twice as high as those in compact bone.

4. The relevance of these findings to the use of fusidic acid therapy as an adjunct to surgical management of chronic osteomyelitis is discussed.

\section{REFERENCES}

Agranat, B. J. (1969): Friedlander's osteomyelitis of the mandible: report of case. Journal of Oral Surgery, 27, 293-295.

Arens, W., and ThIELE, H. (1966): Úber die Behandlung chronisch eitriger Osteomyelitiden mit einem neuartigen Antibiotikum. Fortschritte der Medizin, 84, 31-34.

AXHAUSEN, W. (1961): “Antibiotische Plombierung” osteomyelitischer Knochenherde. Zentralblatt für Chirurgie, 86, 1859-1864.

Barber, M., and Waterworth, P. M. (1962): Antibacterial activity in vitro of Fucidin. Lancet, 1, 931-932.

Bikfalvi, A., and ECKE, H. (1960): Die Behandlung der chronischen Osteomyelitis mit Eigenblut- AntibiotikaPlombe. Bruns' Beiträge zur klinischen Chirurgie, 201, 190-207.

BischofBERGER, C. (1953): Das Krankheitsbild der chronischen Osteomyelitis, Ursache, Behandlung und Folgezustände. Zeitschrift für Orthopädie, 84, 234-268.

Blanke, K. (1952): Osteomyelitistherapie seit Einführung der Antibiotica. Ergebnisse der Chirurgie und Orthopädie, 37, 61-92.

BuYSKe, D. A., EisNer, H. J., and Kelly, R. G. (1960): Concentration and persistence of tetracycline and chlortetracycline in bone. Journal of Pharmacology and Experimental Therapeutics, 130, 150-156.

Chater, E. H. (1963): Clinical trial of Fucidin in bone and joint infections. Irish Journal of Medical Science, sixth series, 367-373.

Clawson, D. K., and Dunn, A. W. (1967): Management of common bacterial infections of bones and joints. Journal of Bone and Joint Surgery, 49-A, 164-182.

COMPERE, E. L. (1962): Treatment of osteomyelitis and infected wounds by closed irrigation with a detergentantibiotic solution. Acta orthopaedica Scandinavica, 32, 324-333.

Crosbie, R. B. (1963): Treatment of staphylococcal infections with "Fucidin". British Medical Journal, $1,788-794$.

Dahmen, G. (1965): Erfahrungen bei der Behandlung der chronischen Osteomyelitis mit Sulfonamiden und Antibiotizis. Chirurgische Praxis, 9, 569-582.

ENDLER, F. (1957): Die medikamentöse Lokalbehandlung der Osteomyelitis und ihre Ergebnisse. Wiener medizinische Wochenschrift, 107, 653-658, 689-694.

FARBer, D. (1962): Über die antibiotische Therapie septischer Prozesse in der Orthopädie. Zeitschrift für Orthopädie, 96, 79-88.

Garrod, L. P., and O'Grady, F. (1971): Antibiotics and Chemotherapy. Edinburgh and London: E. and S. Livingstone. 
Godtfredsen, W. O., Jahnsen, S., Lorck, H., Roholt, K., and Tybring, L. (1962): Fusidic acid: A new antibiotic. Nature (London), 193, 987.

Godtfredsen, W. O., and Vangedal, S. (1962): The structure of fusidic acid. Tetrahedron, 18, 1029-1048.

Harvey, C. L., KNIGHT, S. G., and SiH, C. J. (1966): On the mode of action of fusidic acid. Biochemistry, 5, 3320-3327.

Hierholzer, G. (1970): Pathogenese und Grundlagen der Behandlung bakterieller Infektionen nach Osteosynthesen. Hefte zur Unfallheilkunde, 102, 34-41.

Hierholzer, G., KNOTHE, H., and ReHN, J. (1970): Penetration der Fusidinsäure in aseptisches Knochengewebe. Arzneimittel-Forschung, 20, 1473-1476.

Hierholzer, G., KNOTHE, H., ReHN, J., and Koch, F. (1966): Fusidinsäure-Konzentrationen in chronisch entzündetem Gewebe. Arzneimittel-Forschung, 16, 1549-1552.

Hierholzer, G., Linzenmeier, G., and Knothe, H. (1970): Voraussetzungen für die antibiotische Therapie der post-traumatischen Osteomyelitis. In Die Posttraumatische Osteomyelitis, p. 243. Stuttgart: Schattauer Verlag.

HIERHOLzer, G., and ReHN, J. (1966): Zur Indikation einer zusätzlichen antibiotischen Therapie bei der chronischen Knocheninfektion. Tagung der mittelrheinischen Chirurgenvereinigung, October 6-8, 1966 in Homburg/Saar.

HieRHOLzer, G., and ReHN, J. (1967): Zur antibiotischen Therapie der chronischen Knocheninfektion. 5th Internationaler Kongress für Chemotherapie, June 26-July 1, 1967 in Wien.

HiERHOLZER, G., REHN, J., KOCH, F., and GATOS, M. (1967): Untersuchungen zur chronischen posttraumatischen Osteomyelitis. I. Mitteilung: Beeinflussung des Keimwachstums in Chronisch entzündetem Knochengewebe durch Antibiotika. Bruns' Beiträge zur klinischen Chirurgie, 215, 376-383.

Hilson, G. R. F. (1962): In-vitro studies of a new antibiotic (Fucidin). Lancet, 1, 932-933.

Holloway, W. J., Kahlbaugh, R. A., and Scott, E. G. (1964): Lincomycin: A clinical study. Antimicrobial Agents and Chemotherapy-1963, 200-203.

Jensen, K. A., and KiAer, I. (1964): Fucidin. A study on problems of resistance. I. Acta pathologica et microbiologica Scandinavica, 60, 271-284.

Juch, E. (1953): Behandlung der akuten Osteomyelitis. Langenbecks Archiv und Deutsche Zeitschrift für Chirurgie, 274, 107-112.

KIMmig, J., and Meyer-RoHN, J. (1962): Experimentelle Untersuchungen und klinische Erfahrungen mit dem neuen Antibiotikum Fucidin. Medizinische Welt, 1742-1746.

Kosinzew, A. (1954): Úber radikale chirurgische Behandlung der Chronischen Osteomyelitis. Chirurg, 25, 552-555.

LERCH, H. (1958): Die plastische Deckung unspezifischer osteomyelitischer Knochenhöhlen mit Knochentransplantaten. Zeitschrift für Orthopädie, 89, 374-379.

MURRAY, R. A. (1962): Importance of soft tissue to treatment of chronic osteomyelitis. Journal of the American Medical Association, 180, 198-203.

Neuber, G. (1896): Zur Behandlung starrwandiger Höhlenwunden. Langenbecks Archiv für klinische Chirurgie, 51, 683-716.

Newman, R. L., Bhat, K. M., Hackney, R., Robinson, C., and Stewart, G. T. (1962): Fusidic acid: Laboratory and clinical assessment. British Medical Journal, 2, 1645-1647.

NikITIN, G. D. (1955): Haut-Muskelplastik bei der Therapie schwerer Formen der chronischen Osteomyelitis. Chirurija, 4, 48-52. Abstracted in: Zentralorgan für die gesemten Chirurgie und ihre Grenzgebiete, 140, 226.

RItZerfeld, W. (1964): Zur Fucidine-Wirkung auf Staphylokokken. Zeitschrift für Hygiene, 149, 440-445.

RüHL, R. (1954): Anwendung und Technik plastischer Massnahmen bei osteomyelitischen Knochenhöhlen. Chirurg, 25, 273-277.

SteWART, G. T. (1964): Steroid antibiotics. Pharmakotherapia, 2, 137-148.

Tanaka, N., Yamaki, H., LiN, Y.-C., and UmezaWA, H. (1967): Further studies on inhibition of protein synthesis by fusidic and helvolinic acids. Journal of Antibiotics, Series A, 20, 156-161.

Tanaka, N., Kinoshita, T., and Masukawa, H. (1968): Mechanism of protein synthesis inhibition by fusidic acid and related antibiotics. Biochemical and Biophysical Research Communications, 30, 278-283.

TAYLOR, G., and BLOOR, K. (1962): Antistaphylococcal activity of Fucidin. Lancet, 1, 935-937.

ThÖRMER, H. J. (1960): Die zeitgemässe Behandlung der chronischen Osteomyelitis. Archiv für orthopädische und Unfall-Chirurgie, 52, 247-258.

Willenegger, H. (1963): Therapeutische Möglichkeiten und Grenzen der antibakteriellen Spüldrainage bei chirurgischen Infektionen. Langenbecks Archiv und Deutsche Zeitschrift für Chirurgie, 304, 670-672.

WYNN, S. K. (1960): Immediate skin grafting of the saucerized tibia in chronic osteomyelitis. Journal of the International College of Surgeons, 33, 203-207.

YAMAKI, H. (1965): Inhibition of protein synthesis by fusidic and helvolinic acids, steroidal antibiotics. Journal of Antibiotics, Series A, 18, 228-232.

VOL. 56 B, NO. 4, NOVEMBER 1974 